\title{
SILVER ECONOMY IN EU - LONG-TERM PERSPECTIVES OF LABOUR FORCE STRUCTURE
}

\author{
Antoniu PREDESCU*, Assistant Professor, Ph.D. \\ e-mail: gen3pavo@yahoo.com \\ Maria-Loredana POPESCU*, Assistant Professor, Ph.D. \\ * Spiru Haret University, Faculty of Accounting and Finance, Râmnicu Vâlcea \\ e-mail: popesculrdn@yahoo.com
}

\begin{abstract}
This paper is focused on circumscribing in what manner labour force structure, as distinct economic factor, will influence, in next decades, process of building up a silver economy in EU. For this, we use statistical data, put to use so as to generate a proper prognosis of future increase in size of ageing population in EU, relative to size of total population. This task is accomplished using the strategy of comparing positions of different countries in European Union, the more economically developed Western EU economies and the less developed Eastern EU economies, so that to be able to argue whether European Union has its (certain) opportunities - and, of course, its drawbacks - for constructing its 'silver economy', and, the scope of these opportunities (which necessarily counterbalance drawbacks).
\end{abstract}

Keywords: silver economy, GDP, age, demand, output

JEL Classification: $\mathbf{J}_{08}, \mathbf{J}_{11}, \mathbf{J}_{21}, \mathbf{J}_{49}$

\section{Introduction}

The problem of ageing population is certainly a serious one, in Europe, in particular in European Union. Capacity in which an economy is prepared to deal with this 'illness' determines its further development; for, if Finland, for example, already implemented a strategy, comprising economic and social measures, to cope with all this in the foreseeable future, welfare system, at EU level, may buckle, in next decades, with its (economic and social) burden, if it will have a small financial base, and, comparatively, (too) many beneficiaries.

There is at least an important macroeconomic factor - labour force - that is influenced heavily under the influence of silver economy: labour force structure will most surely alter, in next decades, once European Union's economy will become a silver economy. Knowing how this structure will be changed, and its subsequent (future) profile, is of the outmost importance for management of future 'silver economy'.

Such a state of affairs makes it imperative to assess, using statistical data, on one side, and established economic, demographic and psychological principles, on the other side, long-term perspectives of labour force structure in EU, in the 
background of silver economy, i.e. of known facts concerning structures and dynamics of $a$ - or any - silver economy.

In present moment, specialized (economic) literature concerning silver economy is rather sketchy; even more so is this literature as regards impact and contribution of important macroeconomic factor (dynamics) of labour force structure. The goal of this paper is to focus on this perspective, in order to answer a question such as 'Is European Union's (future) silver economy able to work/grow in long term?'

\section{Literature review}

In general terms, it is known for some time - not that much, actually - that "The notion of silver economy means the adaptability of the economy to the future needs of the growing number of elderly people" (Radvanský and Páleník, 2010). So, from this - reasonable - point of view, European Union has to build its silver economy, but, in addition, this European silver economy must be built on our own, on firm ground, so as to assure a real durable development for Romanian economy, in the long term (Ahtonen, 2012).

A silver economy, in general, therefore EU's silver economy as well is a result of (clear) demographic trends; since the end of age of 'baby boomers' population of senior citizens continually - more or less - rose, until now (2014).

In other words, market itself changes, in particular labour market, existent workers - and to a larger extent future workers - must develop new skills (www.cedefop.europa.eu); as a result, demand and offer either - as of today changed already or must evolve relatively quickly in the future, in order to cope with new/larger consumption preferences of an ever larger senior citizens population and, simultaneously, with a labour market (at best) undergoing some profound changes, of not in turmoil.

Therefore, it is an established fact EU's population is ageing: in other words, in some 30-40 years a relatively large share of this population will consist of senior citizens. This state of fact will undoubtedly effect deep changes in structure of real economy, and also in the mechanism of real economy.

\section{Theoretical background}

In our paper analysis is firmly established on sound economic and statistic reasoning; in particular, we made good use of data provided by EUROSTAT in order to pinpoint the trend of growth of ageing population' numbers in the foreseeable future, in other words the trend of increments silver economy in European Union grows by.

Plotting this data into specific tables and graphs, in order to circumscribe boundaries of present EU silver economy, respectively of future EU silver economy, is, to all accounts and purposes, most important in order to establish a clear and correct image of long-term perspectives of labour force structure, in European Union. 


\section{Dynamics of ageing population in EU}

An ageing population, such as European Union's, (relatively) slowly but surely increasing, as it manifests itself for almost two decades now (2014), makes each and every debate on silver economy, that is on an 'ageing labour force outfitted economy', important and anything but pointless. In fact, one of the most important factors comprised in any given analysis of silver economy is the very issue analysed in this paper: how and especially how long a silver economy will be able to endure as $\boldsymbol{a}$ silver economy?

Such an economy is one impelled by an ageing (at least in relative terms) labour force, in the benefit of a large population consisting of senior citizens - that is, of ageing men and women. And, as proof of this stands the data in the table below, that is prognosis of EU demographic trends in the foreseeable future namely, 2015-2060 period -, as regards persons over 65 years of age:

Dynamics of ageing population in European Union, 2015-2060

Table 1

Table 1

number of

\begin{tabular}{|c|c|c|c|c|c|c|c|c|c|c|}
\hline Year & 2015 & 2020 & 2025 & 2030 & 2035 & 2040 & 2045 & 2050 & 2055 & 2060 \\
\hline $\begin{array}{c}\text { EU27 } \\
- \\
\text { popul } \\
\text { ation, } \\
65 \\
\text { and } \\
\text { over }\end{array}$ & $\begin{array}{c}27,3 \\
97,7 \\
31\end{array}$ & $\begin{array}{l}29,29 \\
0,929\end{array}$ & $\begin{array}{c}31,156 \\
001\end{array}$ & $\begin{array}{c}33,277, \\
281\end{array}$ & $\begin{array}{c}34,299,1 \\
28\end{array}$ & $\begin{array}{c}33,184 \\
154\end{array}$ & $\begin{array}{c}32,326 \\
812\end{array}$ & $\begin{array}{c}32,357 \\
906\end{array}$ & $\begin{array}{l}32,03 \\
8,940\end{array}$ & $\begin{array}{c}30,6 \\
30,6 \\
56\end{array}$ \\
\hline
\end{tabular}

Source: http://appsso.eurostat.ec.europa.eu/nui/submitViewTableAction.do, 2014: authors own computations

The graph illustrating this dynamics is included below:

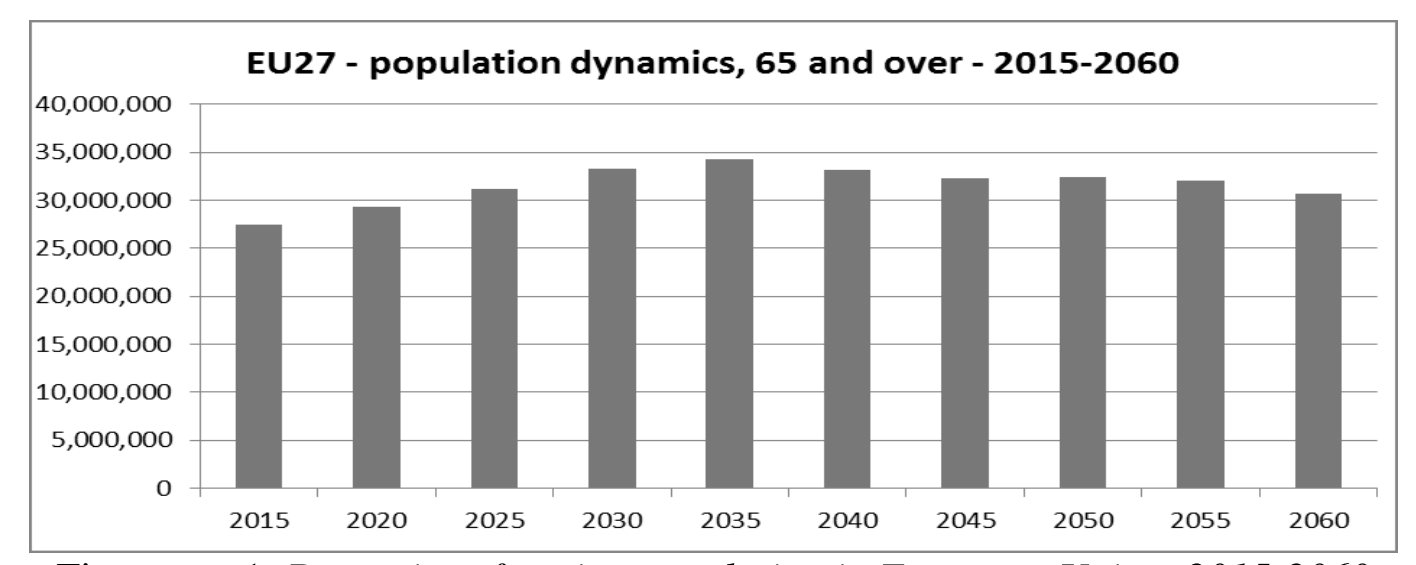

Figure no. 1. Dynamics of ageing population in European Union, 2015-2060

Source: http://appsso.eurostat.ec.europa.eu/nui/submitViewTableAction.do, 2014: authors own computations 
As if this material (i.e., real) and numerical evidence isn't enough, quantifying the future from today's foothold, there is much to be desired in/with today's European Union silver economy, since it is running already out of steam in fact, out of future steam, more precisely using far too quickly what little human reserves it can muster for its present needs and, hopefully, for its future.

\section{Impact of silver economy on labour market}

A silver economy, we recall, is an economy comprising - e.g. as consumers and as labourers - large numbers of old men and women. This, as we will argue further on in this paper, will put the EU economy in a difficult situation, not at all comfortable, an economy whose very functioning is bound to be (extremely) 'expensive'; eventually, because everything boils down to the fact an economy is a silver economy, and not something else: the lack of young employees.

Or, even today, European Union's economy is far from impregnable, in face of such odds, or even prepared to accomplish whatever it will be bound to accomplish: European Union's population is, even today, in such a state of (relatively) senescence, that virtually all persons constituting $E \boldsymbol{U}$ labour force by 2020 - considering today's European laws concerning retirement (age) - is already in work!

On the other side, already in present days only share of workers over 40 years of age is on the rise; consequently, statutory retirement age is, rising steadily is various states of European Union, being only up to states' welfare systems to cope with an ever increasing numbers of tired, ill or simply less-than-utter-efficient workers everywhere in EU.

European Union needs, for its future silver economy of 2040-2050, a labour force structure as 'normal', that is young, as possible; for the time being, however, there are simply too few young workers, and, as yet, not too many (young) children. As a result, and in any theoretical analysis of those facts, such as this analysis, one may think it is fit to conclude EU's economy might just carry on using its present - and future - old workers.

This may seem too good to be true, and, if we put it this way, it is too good to be true. Because, whilst it is feasible, in theoretical terms, for an economy to function using a warped labour force structure, a structure, in other words, stuffed to capacity, and beyond it, with senior citizens, this perspective, in practical - e.g. financial - terms, can very well be a bit too expensive for comfort.

Firstly, skills: as new technologies currently become part of economy, and of production processes - to mention but these processes here -, 'old' workers - in this case, 'old' means 'already hired' - must be trained insofar as to be able to make use of new technologies. But, old people in general tend to be conservative, in other words to dislike new techniques and procedures and, respectively, to cling on to the old way of doing things. For any silver economy, reckoning with this issue is bound to be anything but easy.

Secondly, standards of life: social inclusion is a goal which cannot be ever forgotten, when senior citizens status is analysed. And this analysis is not a straight 
line, given the fact standard of life as regards old people is divided, so to speak, into two realms: one is the very existence of a large number of ageing men and women, and the other is a substantial number of ageing workers - man and women.

\section{Perspectives of EU's silver economy}

A large number of ageing people is in itself a big issue, since it implies existence, in long term, of large financial funds state has to subtract from state budget in order to subsidize retirement benefits. This type of transfer payments will constitute a considerable burden for both state and taxpayers in the long term, too, if that number of retired men and women will not 'contract', i.e. when some of these old persons will once again take a job, and, thus, become ageing workers.

If this is not the case, not only retirement benefits will be huge in size (and implications), but, also, most part of transfer payments will inevitably go (in)to retirement benefits.

States tend, and intent, not to behave simply as spectators of this relatively gloomy dynamics of work market; state manifest themselves for some time in this field, through legislative means - especially influencing age threshold.

Namely, in whole of European Union - and, of course, also in U.S.A., Japan, and so on -, age threshold in on the increase; for, whilst, historically, e.g. in EU generation of 'baby boomers' is (still!) active, states intent to make this generation work longer (at least, longer than previously intended), with the benefit of 'saving' some of financial funds used to make up transfer payments.

This effect is to be obtained by delaying benefit eligibility; considering all this, one can, or even must, ask himself if this delay is not - already - too much of a crisis measure, and, even more so, if it will not be in foreseeable future too much for current workforce to bear.

Fortunately, if we may say so, there seems to be some good part of all these plans to 'allow' senior citizens to work, instead of receiving their pensions, from a purely economic point of view: cause, if senior citizens work, along with younger people, forming, as a result, a bigger work force than it would have been otherwise the case, this will, inevitably - at least at a theoretical level of analysis -, decrease labour cost.

As a result, the situation will (tend to) be one in which economy puts up with lower levels of payroll taxes - levied on both employers and employees.

Old employees tend, at least, in present time, to earn (slightly) less than middle age - for example - employees, and it is doubtful, to say this much, silver economy of European Union will be able to provide them with more, globally. On the other hand, old people relying on public and private pensions can be affected in their strive to enjoy a decent life if pension level is rather low (or, European Union is, still, far from levelled in this respect: pensions in Luxemburg, for example, may well be, in absolute terms - e.g. amount of $€-$, satisfactory, but this is, definitely, not the case i.e. in Romania (Paşnicu D., 2013, p. 12.) or Bulgaria). 


\section{Conclusions}

The main purpose of our paper is to establish conditions in which inherent mechanisms of any silver economy, therefore of (future) EU silver economy, will affect labour force structure, with the respective inherent and unavoidable effects on the economy.

The structure of goods and services dedicated to elderly population is going to undergo changes in EU, because of the increase in the proportion of the elderly in the total population. This, naturally, will pose further complications, this time on labour force - inclusively on its structure.

In a silver economy, where demand and consumption preferences are, on average, significantly different, comparing them with those that characterize a 'mere' (market) economy, employees in all branches of real economy must be (re)trained, be them young or old employees - as we argued above. But, although at it can be grasped - tough in (this) principle, this mechanism is even more difficult to manage in times of (continuous and gradual) rising of statutory retirement age (laws).

Due to this, old employees that must be trained on a regular basis anyway will be trained in the circumstance to the effect they are, so to speak, really old (e.g. over 65 years of age!) and in the same time forced, at least by circumstances/current laws, to work. These workers, considered individually, this work force, globally, are, respectively is, frail, more than a reason for EU silver economy to be faced with yet another problem.

In short, the point will be EU labour market will have to expand, its labour demand as much as labour supply, since labour force (structure) must expand in the first place. There will be, to be sure, a dire need for trainers, in all the fields ageing labourers will work (industry, commerce, services, etc.), and, on the other hand, a similarly large need for people able to keep this 'senior industrial army' fit - first and foremost, fit to work.

Future EU silver economy will need to develop its medical and welfare systems; this, in turn, imposes recruiting and hiring of additional medical, welfare, etc. personnel. And, of course, it will arise another need, the need for an EU strategy for developing, in this manner, and for these goals, EU labour market.

There are a lot of differences in the extent and intensity of ageing among European countries, because countries like Finland and France already implement strategies that could bring them benefits out of their silver economies. West European countries, on the other hand, are ageing faster than east European countries, at that moment, but, some are further ahead than others. The point is that, there is no European country where ageing is not clearly observable.

The problem in European Union is increase in the number of elderly will be accompanied by growing numbers of retired people. From this perspective, our analysis gives at least some hints about circumstances in which aging will be one of the key factors that, in the future will change the economic indicators at EU level, with a more than significant impact. 


\section{REFERENCES}

1. Ahtonen, A. (2012), Healthy and Active Ageing: Turning the 'Silver' Economy into Gold, Policy Brief, European Policy Centre.

2. Descy, Pascaline (18 April 2013), "Demographic Time Bomb or Silver Economy? Turning Risks into Opportunities", Brussels: European Centre for the Development of Vocational Training.

3. Gregory-Mankiw, N. (2003), Principles of Macroeconomics (3rd edition), New York: The McGraw-Hill Companies, Inc.

4. Kotler, Ph., Armstrong, G. (2005), Principiile marketingului (Ediția a 3-a), Bucureşti: Editura Teora.

5. Lipsey, R.G., Chrystal, K. A. (2004), Economics (10 ${ }^{\text {th }}$ edition), U.S.A.: Oxford University Press.

6. Paşnicu, D. (2013), "Action Guidelines for effective manage labour migration, case study for România", Annals of Spiru Haret University, Economic Series, vol. 4(13), issue 1: 11-21.

7. Radvanský, M., Páleník, V. (2010), Silver Economy as Possible Export Direction at Ageing Europe - Case of Slovakia, Bratislava: Slovak Research and Development Agency.

8. Schiller, B.R. (2003), The Economy Today ( $9^{\text {th }}$ edition), New York: The McGraw-Hill Companies, Inc.

9. Štefánik, M. et al. (2013), "Modelling the Economic Potential of the Silver Economy". Neujobs Working Paper No. D 12.3.

10.http://epp.eurostat.ec.europa.eu (2014) 
